Biol. Stud. 2021; 15(2): 3-14 • DOI: https://doi.org/10.30970/sbi.1502.652

www.http://publications.Inu.edu.ua/journals/index.php/biology

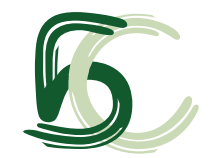

UDC: 577.353

\title{
MODULATING THE MECHANOKINETICS OF SPONTANEOUS CONTRACTIONS OF THE MYOMETRIUM OF RATS USING CALIX[4]ARENE C-90 - PLASMA MEMBRANE CALCIUM ATPase INHIBITOR
}

\section{O. V. Tsymbalyuk}

Taras Shevchenko National University of Kyiv, 64/13 Volodymyrska St., Kyiv 01601, Ukraine

Corresponding author e-mail: otsimbal@univ.kiev.ua

Tsymbalyuk O.V. Modulating the mechanokinetics of spontaneous contractions of the myometrium of rats using calix[4]arene C-90 - plasma membrane calcium ATPase inhibitor. Studia Biologica, 2021; 15(2): 3-14 • DOI: https://doi.org/10.30970/sbi.1502.652

Introduction. Plasma membrane calcium ATPase is a constitutive structure of cells that functions as a high affinity system of releasing $\mathrm{Ca}^{2+}$ ions from the cytoplasm and ensures a long-term maintenance of the basal concentration of these cations in the state of dormancy. Currently, there are no satisfactory means for the pharmacological correction of plasma membrane calcium ATPase function. Thus, elaboration, synthesis, and study of substances with the targeted impact on plasma membrane calcium ATPase are topical issues. Previously, we determined the ability of this calix[4]arene in the concentration of $10 \mu \mathrm{M}$ to inhibit the contractive activity and to slow down the relaxation of smooth muscle of the myometrium in the NO-dependent way, which considerably decreases the normalized maximal velocity of the relaxation phase.

Materials and Methods. The tenzometric methods and mechanokinetic analysis were used to investigate the impact of the cumulative increase in the concentration of calix[4]arene C-90 $(10 \mathrm{nM}-100 \mu \mathrm{M})$ on the spontaneous contractive activity of the myometrium of rats. The complete profile of spontaneous cycles of contractions-relaxations was studied by the empirical multiparameter method of complex mechanokinetic analysis, elaborated by us (with the consideration of the parameters of time $\left(\tau_{0}, \tau_{\mathrm{C}}\right.$ and $\left.\tau_{\mathrm{R}}\right)$, force $\left(F_{\max }, F_{\mathrm{C}}\right.$ and $\left.F_{\mathrm{R}}\right)$, velocity $\left(V_{\mathrm{C}}\right.$ and $\left.V_{\mathrm{R}}\right)$, and impulse $\left(I_{\max }, I_{\mathrm{C}}\right.$ and $\left.I_{\mathrm{R}}\right)$.

Results. Calix[4]arene C-90 evoked the dose-dependent inhibition of spontaneous contractive activity of the myometrium preparations. Its high concentrations caused a change in the structure of the contraction act, such as an increase in the duration of the contraction phase, while the duration of the relaxation phase did not show any changes.

The multiparameter method of the complex mechanokinetic analysis demonstrated that in the whole range of the investigated concentrations, substance C-90 considerably

() 2021 O. V. Tsymbalyuk. Published by the Ivan Franko National University of Lviv on behalf of Біологічні Студії / Studia Biologica. This is an Open Access article distributed under the terms of the Creative Commons Attribution License (http://www.budapestopenaccessinitiative.org and Creative Commons Attribution 4.0 License), which permits unrestricted reuse, distribution, and reproduction in any medium, provided the original work is properly cited.

ISSN 1996-4536 (print) • ISSN 2311-0783 (on-line) • Біологічні Студії / Studia Biologica • 2021 • Том 15 / № 2 • C. 3-14 
decreases the indices of force parameters $\left(F_{\max }, F_{\mathrm{C}}\right.$ and $\left.F_{\mathrm{R}}\right)$ and the values of impulses of force $I_{\max }, I_{\mathrm{C}}$ and $I_{\mathrm{R}}$ of the spontaneous contractions of the myometrium. On the background of all the applied concentrations $\left(10^{-7}-10^{-4} \mathrm{M}\right)$, calix[4]arene C-90 conditioned the slowing down of the relaxation of spontaneous contractions in uterine muscle preparations of rats, which was reflected in a reliable decrease in the parameter for the maximal velocity of the relaxation phase $\left(V_{R}\right)$.

Conclusions. The results of the study demonstrate that calix[4]arene C-90 inhibits the processes of $\mathrm{Ca}^{2+}$ extrusion from smooth muscle cells myoplasm, probably, impacting plasma membrane calcium ATPase molecules directly. It is noteworthy that C-90 is also likely to inhibit the processes of the intake of these cations to cells from the extracellular medium, causing a decrease in the velocity of force intensification during the contraction phase, and reducing the frequency and force of the spontaneous contractions in the myometrium.

Keywords: smooth muscles, myometrium, plasma membrane calcium ATPase, calix[4]arene C-90, mechanokinetic analysis

\section{INTRODUCTION}

The control of excitation and contractive activity of uterine smooth muscles (SM) ensures the preservation of the fertility and the ability to bear the fetus and survive the delivery $[17,24]$. According to the data of the World Health Organization, many cases of newborns' death globally are related to premature delivery, the cellular basis of which is the impaired regulation of the processes of excitation-contraction in the myometrium [26].

The systems of active ion transport in the plasma membrane and intracellular calcium depots are relevant regulators in the functioning of uterine SMs. In particular, noteworthy are the systems of active transport for $\mathrm{Ca}^{2+}$ ions: calcium pumps of plasma membrane (PM) and sarcoplasmic reticulum, $\mathrm{Na}^{+} / \mathrm{Ca}^{2+}$-exchanger in $\mathrm{PM}, \mathrm{Ca}^{2+}$ transporting systems in mitochondria, which maintain the basal level (about $100 \mathrm{nM}$ ) of the intracellular concentration of this cation, and ensure the termination of excitation processes $[9,13]$.

Plasma membrane calcium ATPase (PMCA) is a constitutive structure of PM of cells that functions as a high affinity $\left(\mathrm{K}_{\mathrm{M}}\right.$ for $\mathrm{Ca}^{2+}$ is $\left.0.2-0.5 \mu \mathrm{M}\right)$ system of releasing $\mathrm{Ca}^{2+}$ ions from the cytoplasm. It ensures a long-term maintenance of the basal concentration of these cations in the state of dormancy. PMCA belongs to the family of ion-transporting ATPases of P-type (subclass P2B) [14]. The stoichiometry of the transported $\mathrm{Ca}^{2+}$ ions and hydrolyzed ATP molecules is 1:1. Four isoforms of PMCA (1-4) were identified, which are encoded by different genes; the additional diversity (over 20) of isoforms is ensured by the alternative splicing [6].

While pumping $\mathrm{Ca}^{2+}$ out of smooth muscle cells (SMC), PMCA is involved in the maintenance of the intracellular concentration of these cations, and the contribution of this calcium-transporting system in maintaining the basal intracellular concentration of $\mathrm{Ca}^{2+}$ in the myometrium cells is $70 \%$, while the remaining $30 \%$ are ensured by $\mathrm{Na}^{+} / \mathrm{Ca}^{2+}$-exchanger [8].

During the two recent decades, many studies, actively conducted globally by different laboratories, have demonstrated that in terms of tissues and isoforms, PMCA is one of the key membrane structures with $\mathrm{Ca}^{2+}$-transporting and signaling functions and is related to the development of many pathologies, for instance, hypertension, myocardial

ISSN 1996-4536 (print) • ISSN 2311-0783 (on-line) • Біологічні Студії / Studia Biologica • 2021 • Том 15 / № 2 • С. 3-14 
hypertrophy, neuronal damage, male sterility, etc., which indicates considerable therapeutic potential of PMCA [16]. Currently, there are no satisfactory means for the pharmacological correction of PMCA function.

Two classes of substances capable of inhibiting PMCA can be distinguished: nonselective inhibitors of ion-transporting systems of the cell (vanadate, eosin, and lanthanum) and caloxins - selective PMCA inhibitors with low affinity (with the constant of enzyme inhibition from human erythrocytes PM for different caloxins varies from 86 to $1,000 \mu \mathrm{M})$. There is an urgent issue of elaboration, synthesis, and study of substances with the targeted impact on PMCA using different models [12].

Recent studies have found that some substances that belong to the class of calixarenes are capable of selective inhibition of $\mathrm{Ca}^{2+}, \mathrm{Mg}^{2+}$-ATPase of PM; for instance, calix[4]arene C-90 impacts this system with $I_{0.5}=34.6 \pm 6.4 \mu \mathrm{M}[4,9,22,23]$. Previously, we determined the ability of this calix[4]arene in the concentration of $10 \mu \mathrm{M}$ to inhibit the contractive activity and to slow down the relaxation of SM in the myometrium in the NO-dependent way, which considerably decreases the normalized maximal velocity of the relaxation phase [3].

The aim of this study was to investigate the mechanokinetic regularities of the impact of the cumulative increase in the concentration of calix[4]arene C-90 (10 nM $100 \mu \mathrm{M}$ ) on the spontaneous contractive activity of the myometrium of rats.

\section{MATERIALS AND METHODS}

The experiments were conducted using Wistar line rats (6 animals, 200-250 g). All the manipulations with animals were conducted according to the International convention for the protection of animals and the Law of Ukraine "On Protection of Animals from Cruelty" (the Minutes of the meeting of Bioethics Commission of SSC Institute of Biology and Medicine No. 3 dated May 2, 2020). The animals were killed by the introduction of a lethal dose of propofol (Sigma, USA) narcosis.

The tenzometric experiments were conducted on preparations of longitudinal smooth muscles of uterine horns. Muscle stripes (the average size $-2 \times 10 \mathrm{~mm}$ ) were placed into a working chamber (the volume of $2 \mathrm{~mL}$ ) with the flowing Krebs solution (the flow rate of $5 \mathrm{~mL} / \mathrm{min}$ ), thermostated at $37^{\circ} \mathrm{C}$. The preparation was passively tensed at $10 \mathrm{mN}$ and left for $1 \mathrm{~h}$ (until the stable amplitude of spontaneous contractions was achieved). The contractive activity was studied in the isometric mode using a force sensing device. The signals were registered with an analogue-to-digital transformer.

Krebs solution contained (mM): $120.4 \mathrm{NaCl} ; 5.9 \mathrm{KCl} ; 15.5 \mathrm{NaHCO}_{3} ; 1.2 \mathrm{NaH}_{2} \mathrm{PO}_{4}$; $1.2 \mathrm{MgCl}_{2} ; 2.5 \mathrm{CaCl}_{2} ; 11.5$ glucose. $\mathrm{pH}$ of the solution was 7.4 .

Calix[4]arene C-90 was synthesized and described by NMR and IR spectroscopy under the leadership of the full member of the NASU V.I. Kalchenko, at the Phosphoranes Chemistry Department of the Institute of Organic Chemistry, NAS of Ukraine.

Calix[4]arene C-90 was preliminary dissolved in dimethylsulfoxide (DMSO) and added to Krebs solution to obtain the final aliquot of DMSO of $0.1 \%$ from the total volume of Krebs solution. The control contractions were studied in solutions containing $0.1 \%$ DMSO.

The scheme of the experiments was as follows: after 10 min of preincubation with calix[4]arene C-90 (10 nM), spontaneous contractions were registered for another $10 \mathrm{~min}$ to conduct the mechanokinetic analysis, then the cumulative increase in the

ISSN 1996-4536 (print) • ISSN 2311-0783 (on-line) • Біологічні Студії / Studia Biologica • 2021 • Том 15 / № 2 • С. 3-14 
concentration of C-90 was achieved (up to $100 \mathrm{nM}$ ), followed by the preincubation for $10 \mathrm{~min}$. After that, the contractions were registered for another $10 \mathrm{~min}$ with subsequent analysis using the kinetic methods, described below; therefore, the increase in the concentration of calix[4]arene C-90 was conducted until reaching $100 \mu \mathrm{M}$.

The efficiency of the contractive activity in muscles was evaluated by the duration of contractions, the pauses between them, the duration of specific fragments of contractions (contraction and relaxation phases), the asymmetry coefficient (the ratio between the duration of the contraction phase and the duration of the relaxation phase), the contractive cycle (the duration of a single contraction and a pause thereafter), the index of activity for contractions (the ratio between the duration of contractions and the duration of pauses between them) [11]. The contraction phase was defined as a fragment of a contractive response from the beginning of force variation up to its maximal value (the amplitude of the phase contraction). The relaxation phase started with the maximum of phase contraction and lasted until the value of the force returned to its basal level. The average velocity of the contraction intensification $\left(F_{\text {max }} / t\right.$, the ratio between the contraction amplitude and the time of its attainment) was also determined. The changes in the efficiency of cumulative contractive activity of SM preparations were quantitatively determined in the $\mathrm{MU}$ and $\mathrm{AU}$ indices of contractions (MU, the product of $\mathrm{MU}$ and the average duration of contractions in $10 \mathrm{~min}$ ) [3, 11].

The complete profile of the spontaneous cycles of contractions-relaxations was studied by the empirical multiparameter method of complex mechanokinetic analysis, elaborated by us (with the consideration of the parameters of time $\left(\tau_{0}, \tau_{C}\right.$ and $\left.\tau_{R}\right)$, force $\left(F_{\text {max }}, F_{\mathrm{C}}\right.$ and $\left.F_{\mathrm{R}}\right)$, velocity $\left(V_{\mathrm{C}}\right.$ and $\left.V_{\mathrm{R}}\right)$, and impulse $\left(I_{\max }, I_{\mathrm{C}}\right.$ and $\left.I_{\mathrm{R}}\right)$ [16]. According to this method, single spontaneous contractions were linearized in the coordinates $\left[\ln \left(\frac{f_{\mathrm{R}}}{f_{\mathrm{C}}}\right) ; \ln (1+\Delta t / t)\right]$, where $f$ and $t$ are instantaneous values of force and time on the level of the phases of contraction (marked with index "C") and relaxation (marked with index "R") of the contraction cycle. The parameters are as follows:

- $F_{\mathrm{C}}$ and $F_{\mathrm{R}}-$ relevant values of force in the inflexion points of the mechanokinetic curve on the level of the phases of contraction (from the beginning of the force increase up to its maximal value $F_{\text {max }}$ ) and relaxation (from the maximal value of the force $F_{\max }$ and to its coming back to the basal level);

- $\tau_{\mathrm{C}}$ and $\tau_{\mathrm{R}}$ - indices of the characteristic time of the contraction phase (the time, during which $F_{\mathrm{C}}$ is registered) and the relaxation phase (the time, during which $F_{\mathrm{R}}$ is registered);

- $\tau_{0}$ - typical time of the amplitude (the time, during which $F_{\max }$ is registered);

- $V_{\mathrm{C}}$ and $V_{\mathrm{R}}$ - maximal velocities of the contraction and relaxation phases, respectively;

- $I_{\max }$ - the impulse of the force on the level of the amplitude $F_{\max }$;

- $I_{\mathrm{C}}$ and $I_{\mathrm{R}}$ - the impulse of the force on the level of maximal velocities of contraction and relaxation, respectively.

The kinetics of spontaneous contractions was additionally analyzed using the method of maximal velocity $\left(V_{n r}\right)$ of the relaxation phase, normalized as per the amplitude $\left(F_{\max }\right)$ [1]. The method envisages the separate linearization of the relaxation phase of the mechanokinetic curve in the coordinates $\left[\ln \left(\frac{F_{\max }-f}{f}\right) ; \ln (t)\right]$, where $f$ and $t$ are
instantaneous values of force and time. 
The data were processed by variation statistics methods using OriginPro 2018 program. The samples were checked in terms of belonging to normally distributed general populations according to Shapiro-Wilk criterion. The one-way ANOVA was used to determine reliable differences between the mean values of samplings; the post-test comparison was made using Bonferroni test. In all cases, the results were considered reliable on condition of the probability $p$ value under $5 \%(p<0.05)$. The validation analysis of data approximation by the linear function was performed using Fisher's F-criterion; determination coefficients $\left(R^{2}\right)$ were at least 0.9 . The results were presented as the arithmetic mean \pm standard error of the mean value, $n$ - number of experiments.

\section{RESULTS AND DISCUSSION}

A cumulative increase in the concentration of calix[4]arene C-90 from $10 \mathrm{nM}$ to $100 \mu \mathrm{M}$ in the washing solution was accompanied by a dose-dependent inhibition of spontaneous contractive activity of the myometrium preparations (Fig. 1). It was reflected in the reduction in the amplitude and the frequency of contractions, reliable changes in which were observed in the presence of high C-90 concentrations (10 and $100 \mu \mathrm{M})$. The reduction in the frequency of contractions was caused by the prolongation of the duration of the uterine cycle. It should be noted that the parameter of the uterine cycle duration under the action of C-90 (the range of concentrations $100 \mathrm{nM}-10 \mu \mathrm{M}$ ), was $120 \%$ on average, and under $100 \mu \mathrm{M}$ increased up to $133 \%$, as compared with the control (Fig. 2).

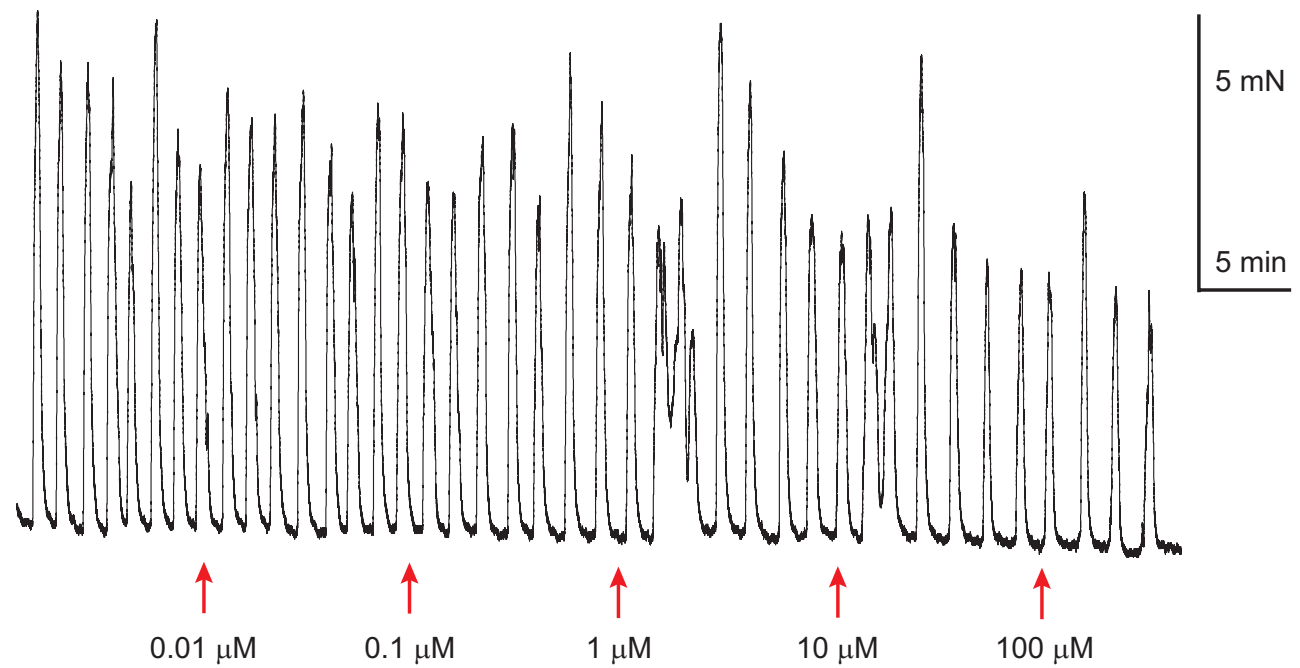

Fig. 1. Spontaneous contractive activity of the myometrium of rats under the cumulative increase in the concentration of calix[4]arene C-90 $\left(10^{-8}-10^{-4} \mathrm{M}\right)$ in the washing solution for smooth muscle preparations. A typical mechanogram is presented

Рис. 1. Спонтанна скорочувальна активність міометрія щурів в умовах кумулятивного збільшення концентрації калікс[4]арену C-90 $\left(10^{-8}-10^{-4} \mathrm{M}\right)$ в омиваючому гладеньком'язові препарати розчині. Наведено типову механограму

The index of contractive activity of the muscle preparations was found to be sensitive to the effect of calixarene, as reliable dose-dependent changes in this index were observed in the whole range of the investigated C-90 concentrations. For instance, in the presence of calix[4]arene C-90 in the concentration of $100 \mu \mathrm{M}$, this parameter

ISSN 1996-4536 (print) • ISSN 2311-0783 (on-line) • Біологічні Студії / Studia Biologica • 2021 • Том 15 / № 2 • С. 3-14 
decreased by $60 \%$ on average as compared with the control (Fig. 2). Also, in the presence of calix[4]arene C-90, there was a considerable dose-dependent increase in the duration of the intervals between some contractions, and reliable changes were observed in the whole range of C-90 concentrations, reaching $202 \%$ under maximal concentration of this compound.

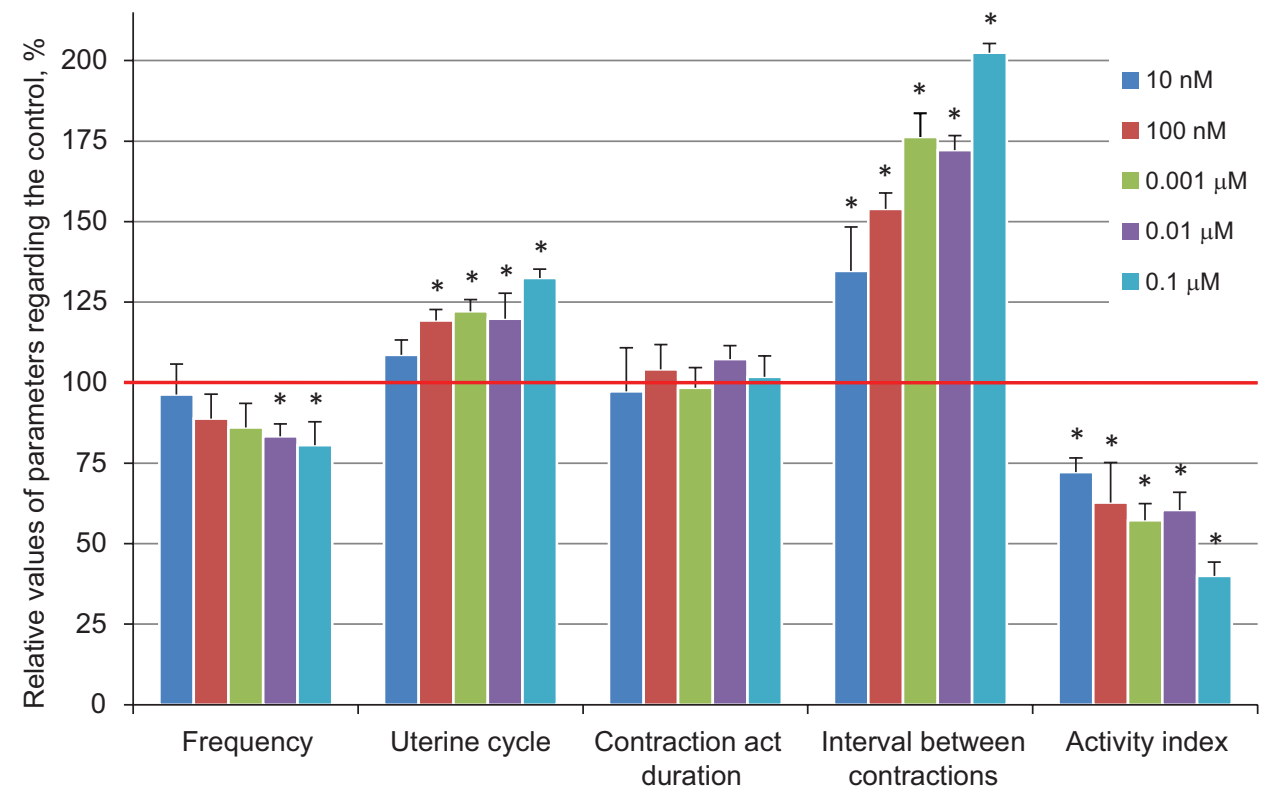

Fig. 2. The parameters of spontaneous contractive activity of the myometrium of rats under the cumulative increase in the concentration $(10 \mathrm{nM}-100 \mu \mathrm{M})$ of calix[4]arene C-90: frequency, uterine cycle, duration of the contraction act, interval between contractions, index of contractive activity. The relevant indices of spontaneous activity in the control $\left(n=6,{ }^{*}-p<0.05-\right.$ the difference is reliable regarding the control) are accepted as $100 \%$

Рис. 2. Параметри спонтанної скорочувальної активності міометрія щурів за кумулятивного збільшення концентрації (10 нM - 100 мкM) калікс[4]арену С-90: частота, матковий цикл, тривалість скоротливого акту (contraction act duration), інтервал між скороченнями (interval between contractions), індекс скоротливої активності (activity index). За 100\% прийнято відповідні показники спонтанної активності в контролі ( $n=6,{ }^{*}-p<0,05$ - різниця достовірна щодо контролю)

Though under preincubation of uterine smooth muscles with calix[4]arene C-90 the duration of some spontaneous contractions did not change, its high concentrations caused a change in the structure of the contraction act. There was an increase in the duration of the contraction phase, while the absolute values for the duration of the relaxation phase did not demonstrate any statistically significant changes (Fig. 3). Under these conditions, calix[4]arene C-90 $(100 \mu \mathrm{M})$ caused an increase in the index of contraction act asymmetry (up to $132 \%$, on average, as compared with the control contractions).

The prolongation of the contraction phase duration along with the simultaneous reduction in the amplitude resulted in a decrease in the index of average velocity of the contraction intensification $\left(F_{\max } / t\right)$, which, for instance, in the presence of calix[4]arene C-90 in the concentration of $100 \mu \mathrm{M}$ was $66 \%$ on average as compared with the control (Fig. 3). Similar effects, such as a considerable increase in the characteristic time of the contraction phase $\left(\tau_{\mathrm{C}}\right)$ and the maximum contraction velocity $\left(V_{\mathrm{C}}\right)$, were observed under the effect of C-90 in the range of concentrations of 1-100 $\mu \mathrm{M}$ (Fig. 4A). 


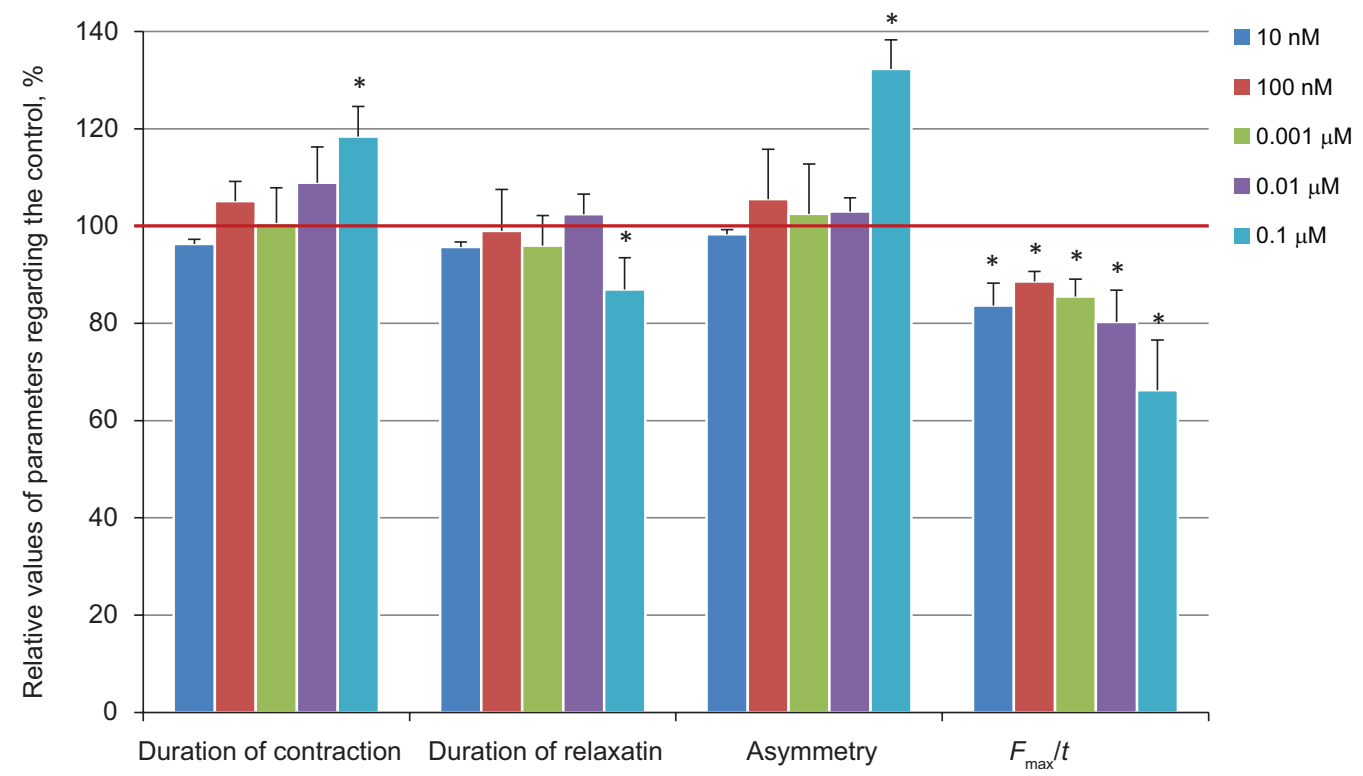

Fig. 3. The parameters of spontaneous contractive activity of the myometrium of rats under the cumulative increase in the concentration $(10 \mathrm{nM}-100 \mu \mathrm{M})$ of calix[4]arene C-90: contraction time, relaxation time, asymmetry of the contraction act (asymmetry), average velocity of the contraction intensification $\left(F_{\max } l t\right)$. The relevant indices of spontaneous activity in the control $\left(n=6,{ }^{*}-p<0.05-\right.$ the difference is reliable regarding the control) are accepted as $100 \%$

Рис. 3. Параметри спонтанної скорочувальної активності міометрія щурів за умови кумулятивного збільшення концентрації (10 нM - 100 мкМ) калікс[4]арену С-90: час скорочення, час розслаблення, асиметрія скоротливого акту (asymmetry), середня швидкість наростання скорочення $\left(F_{\max } / t\right)$. 3а 100 \% прийнято відповідні показники спонтанної активності в контролі $\left(n=6,{ }^{*}-p<0,05-\right.$ різниця достовірна щодо контролю)

It is known that the slowing down of the intensification of the force of spontaneous phase contractions in visceral SM is mainly conditioned by suppressing the intake of $\mathrm{Ca}^{2+}$ ions to SMC from the extracellular space via potential-governed $\mathrm{Ca}^{2+}$-channels $[2,7]$. Thus, it can be inferred that under preincubation of myometrium preparations with calix[4]arene C-90, there process of the intake of this cation via the plasma membrane is suppressed; this effect may cause a general decrease in the activity index of uterine contractions.

The multiparameter method of the complex mechanokinetic analysis demonstrated that in the whole range of the investigated concentrations, substance C-90 considerably decreases the indices of force parameters $\left(F_{\max }, F_{\mathrm{C}}\right.$ and $\left.F_{\mathrm{R}}\right)$ and the values of the impulses of force $I_{\max }, I_{C}$ and $I_{R}$ of the spontaneous contractions of the myometrium (Fig. 4B and C).

As the previous biochemical studies had decisively proven that calix[4]arene C-90 has selective influence on the systems of primary active transport of $\mathrm{Ca}^{2+}$ into uterine SMC (first and foremost, due to PMCA inhibition) [4, 22, 23], our further studies were related to the mechanokinetic analysis of relaxation processes of spontaneous phase contractions of the myometrium preparations. The relaxation process in visceral SM is accompanied by a reduction in the intracellular concentration of $\mathrm{Ca}^{2+}$ ions in the myoplasm [7, 10, 17, 19-21]. 

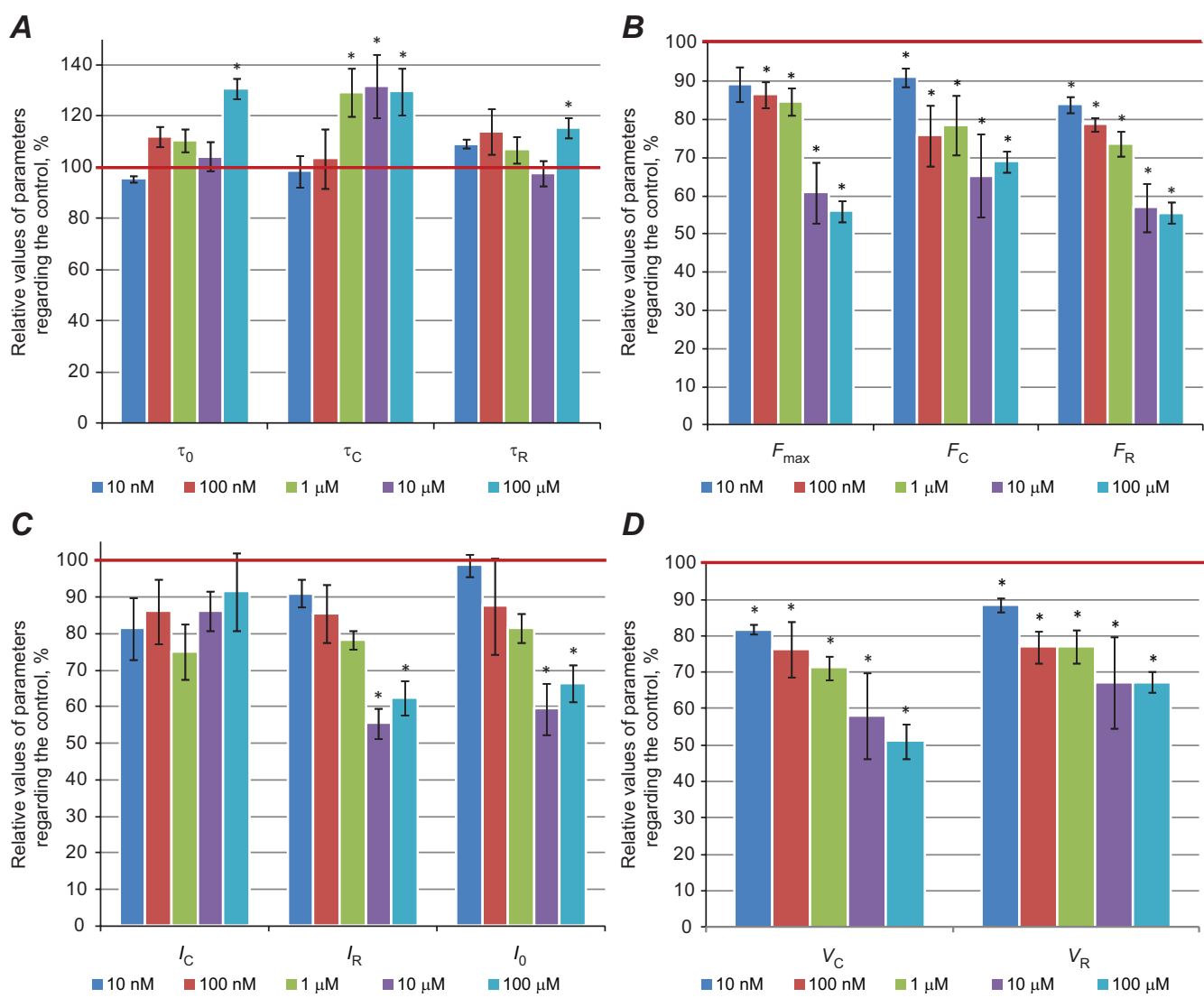

D

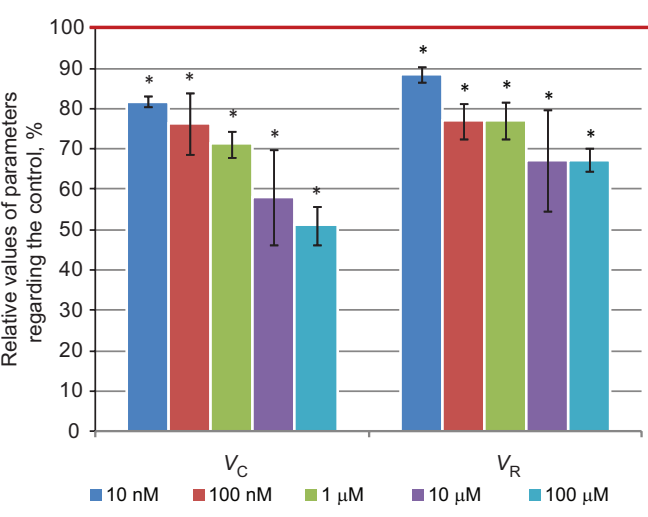

Fig. 4. The parameters of spontaneous contractive activity of the myometrium of rats under the cumulative increase in the concentration $(10 \mathrm{nM}-100 \mu \mathrm{M})$ of calix[4]arene C-90: $\boldsymbol{A}$ - time parameters $\left(\tau_{0}, \tau_{\mathrm{C}}\right.$ and $\left.\tau_{\mathrm{R}}\right) ; \boldsymbol{B}$ - force parameters $\left(F_{\max }, F_{\mathrm{C}}\right.$ and $\left.F_{\mathrm{R}}\right) ; \boldsymbol{C}$ - impulse parameters $\left(I_{\max }, I_{\mathrm{C}}\right.$ and $\left.I_{\mathrm{R}}\right) ; \boldsymbol{D}$ - velocity parameters $\left(V_{C}\right.$ and $\left.V_{R}\right)$. The relevant indices of spontaneous activity in the control $\left(n=6,{ }^{*}-p<0.05-\right.$ the difference is reliable regarding the control) are accepted as $100 \%$

Рис. 4. Параметри спонтанної скорочувальної активності міометрія щурів за умови кумулятивного збільшення концентрації (10 нM - 100 мкМ) калікс[4]арену C-90: $\boldsymbol{A}$ - часові параметри $\left(\tau_{0}, \tau_{\mathrm{C}} \mathrm{i} \tau_{\mathrm{R}}\right)$; $\boldsymbol{B}$ - силові параметри $\left(F_{\max }, F_{\mathrm{C}}\right.$ та $\left.F_{\mathrm{R}}\right) ; \boldsymbol{C}$ - імпульсні параметри $\left(I_{\max }, I_{\mathrm{C}}\right.$ та $\left.I_{\mathrm{R}}\right) ; \boldsymbol{D}$ - швидкісні параметри $\left(V_{\mathrm{C}}\right.$ i $\left.V_{\mathrm{R}}\right)$. За $100 \%$ прийнято відповідні показники спонтанної активності в контролі $(\mathrm{n}=6$, * - p $<0,05$ - різниця достовірна щодо контролю)

On the background of all the applied concentrations $\left(10^{-7}-10^{-4} \mathrm{M}\right)$, calix[4]arene C-90 conditioned the slowing down of the relaxation of spontaneous contractions in uterine muscle preparations of rats, which was reflected in a reliable decrease in the parameter for the maximal velocity of the relaxation phase $\left(V_{R}\right)$ (Fig. 4D). As this parameter is indirectly sensitive to the amplitude of the contractions, we further used the method described in [1] to determine the index of the normalized maximal velocity of the relaxation phase $\left(V_{\mathrm{nr}}\right)$. It was found that a reliable decrease in $V_{\mathrm{nr}}$ was observed under high concentrations $\left(10^{-5}\right.$ and $\left.10^{-4} \mathrm{M}\right)$ of calix[4]arene C-90 (Fig. 5).

Several processes are involved in the relaxation of the myometrium: the main contribution is made by the pumping of $\mathrm{Ca}^{2+}$ outside the cell through the PM (energy-dependent transport systems - PMCA and $\mathrm{Na}^{+}, \mathrm{Ca}^{2+}$-exchanger), much less significant contribution

ISSN 1996-4536 (print) • ISSN 2311-0783 (on-line) • Біологічні Студії / Studia Biologica • 2021 • Том 15 / № 2 • С. 3-14 
is made by the pumping into intracellular $\mathrm{Ca}^{2+}$-depots $\left(\mathrm{Ca}^{2+}\right.$-uniporter of mitochondria and CPKA) [7, 24]. Besides, due to an increased repolarization of PM, activation of $\mathrm{Ca}^{2+}$-sensitive $\mathrm{K}^{+}$-channels and increased work of $\mathrm{Na}^{+}, \mathrm{K}^{+}-\mathrm{ATP}$ ase lead to relaxation [24, 25]. Experiments on the model of the PM suspension of pig uterine myocytes have shown that in addition to a significant inhibition of PMKA, calixarene C-90 is capable of suppressing the CPKA $\left(I_{50}\right.$ values for PMKA and CPKA are $20.2 \pm 0.5 \mu \mathrm{M}$ and $57.0 \pm 1.4 \mu \mathrm{M}$, respectively) to some extent [22]. As shown by A. Shmigol et al. [15] blocking CPKA with thapsigargin causes prolongation of $\mathrm{Ca}^{2+}$-transientives caused by agonists, and plays a significant role in the generation of spontaneous contractions in uterus. Thus, it cannot be ruled out that the mechanokinetic effects of calix[4]arene C-90 observed in our experiments, in addition to the direct effect on PMCA, also contribute to the ability of this compound to suppress CPKA, as well as secondary processes associated with an increased level of $\mathrm{Ca}^{2+}$ in myocytes.

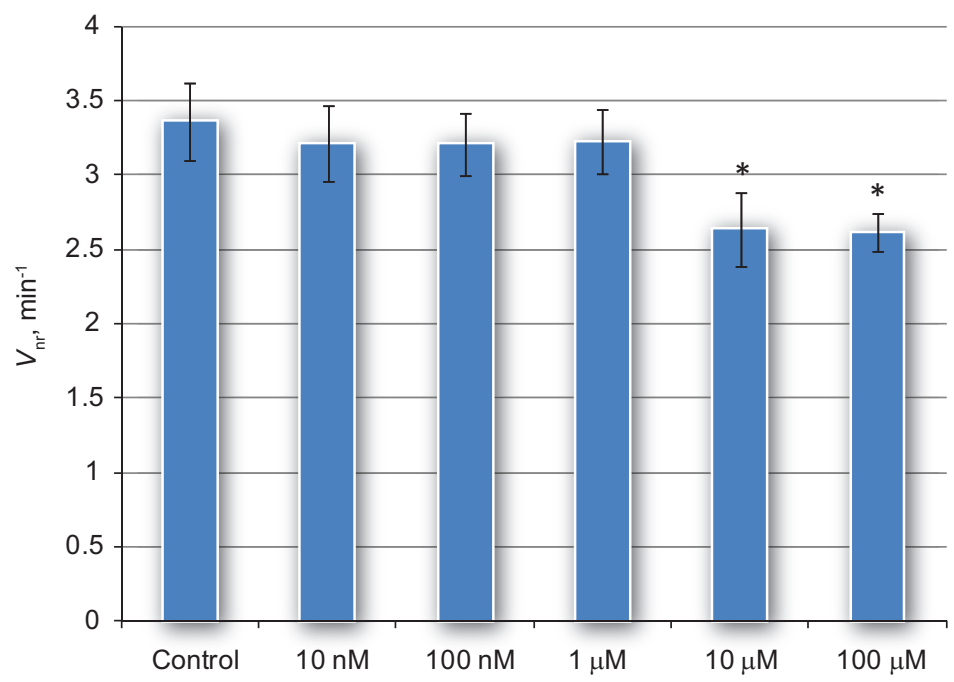

Fig. 5. The normalized maximum velocity $\left(V_{\mathrm{n}}, \mathrm{min}^{-1}\right)$ of spontaneous contractions in the myometrium of rats under the cumulative increase in the concentration $(10 \mathrm{nM}-100 \mu \mathrm{M})$ of calix[4]arene C-90. * $-p<0.05-$ the reliability of changes as compared with the control

Рис. 5. Нормована максимальна швидкість $\left(V_{n}, x^{-1}\right)$ спонтанних скорочень міометрія щурів за умови кумулятивного збільшення концентрації (10 нM - 100 мкM) калікс[4]арену С-90. * - p<0,05 - різниця достовірна щодо контролю

\section{CONCLUSIONS}

The results of the conducted study on the regularities in the myometrium functioning under the cumulative effect (the range of concentrations $-10 \mathrm{nM}-100 \mu \mathrm{M}$ ) of calix[4]arene C-90 demonstrate that this substance inhibits the processes of $\mathrm{Ca}^{2+}$ extrusion from SMC myoplasm, probably by impacting PMCA molecules directly. It is noteworthy that C-90 is also likely to inhibit the processes of the intake of these cations to SMC from the extracellular medium, causing a decrease in the velocity of force intensification during the contraction phase and reducing the frequency and force of the spontaneous contractions in the myometrium. Thus, our results demonstrate that calix[4] arene $\mathrm{C}-90$ is a promising substance that may serve as a basis for the elaboration of medical preparations with a mild tocolytic effect. 


\section{ACKNOWLEDGMENTS}

The author is thankful to S. O. Kosterin, a Member of NAS of Ukraine (Palladin Institute of Biochemistry of NAS of Ukraine), for discussions and valuable commentsand, V. I. Kalchenko, a Member of NAS of Ukraine and PhD R.V. Rodik (Institute of Organic Chemistry of NAS of Ukraine) for the kindly provided calix[4]arene C-90.

\section{COMPLIANCE WITH ETHICAL STANDARDS}

Conflict of Interest: The authors declare that the research was conducted in the absence of any commercial or financial relationships that could be construed as a potential conflict of interest.

Human Rights: This article does not contain any studies with human subjects performed by any of the authors.

Animal Studies: All institutional, national and institutional guidelines for the care and use of laboratory animals were followed.

1. Burdyga Th.V., Kosterin S.A. Kinetic analysis of smooth muscle relaxation. General Physiology and Biophysics, 1991; 10: 589-598.

Google Scholar

2. Burdyga T., Lang R.J. Excitation-contraction coupling in ureteric smooth muscle: mechanisms driving ureteric peristalsis. Smooth Muscle Spontaneous Activity, 2019; 1124: 103-119.

Crossref $\bullet$ PubMed $\bullet$ Google Scholar

3. Feinstein N., Torgersen K.L., Atterbury J. AWHONN's Fetal Heart Monitoring Principles and Practices. (ed. 3). Kendall-Hunt, Dubuque, IA2003. Google Scholar

4. Kosterin S.O., Kalchenko V.I., Veclich T.O., Babich L.G., Shlykov S.G. Calixarenes as modulators of ATP-hydrilizing systems of smooth muscles. Kyiv: Naukova Dumka, 2019. 254 p. (In Ukrainian)

5. Kosterin S., Tsymbalyuk O., Holden O. Multiparameter analysis of mechanokinetics of the contractile response of smooth muscles. Series on Biomechanics, 2021: 35(1); 14-30

6. Lopreiato R., Giacomello M., Carafoli E. The plasma membrane calcium pump: new ways to look at an old enzyme. Journal of Biological Chemistry, 2014; 289(15): 10261-10268.

Crossref $\bullet$ PubMed $\bullet$ PMC $\bullet$ Google Scholar

7. Malik M., Roh M., England S.K. Uterine contractions in rodent models and humans. Acta Physiologica, 2021; 231(4): e13607.

Crossref $\bullet$ PubMed $\bullet$ PMC $\bullet$ Google Scholar

8. Matthew A., Shmygol A., Wray S. Ca ${ }^{2+}$ entry, efflux and release in smooth muscle. Biological Research, 2004; 37(4): 617-624.

Crossref $\bullet$ PubMed $\bullet$ Google Scholar

9. Mazur I.I., Veklich T.O., Shkrabak O.A., Mohart N.A., Demchenko A.M., Gerashchenko I.V., Rodik R.V., Kalchenko V.I., Kosterin S.O. Selective inhibition of smooth muscle plasma membrane transport $\mathrm{Ca}^{2+}, \mathrm{Mg}^{2+}$-ATPase by calixarene $\mathrm{C}-90$ and its activation by IPT-35 compound. General Physiology and Biophysics, 2018; 37(2): 223-231.

Crossref $\bullet$ PubMed $\bullet$ Google Scholar

10. Munoz-Perez V.M., Ortiz M.I., Gerardo-Munoz L.S., Carino-Cortes R., Salas-Casas A. Tocolytic effect of the monoterpenic phenol isomer, carvacrol, on the pregnant rat uterus. Chinese Journal of Physiology, 2020; 63(5): 204-210.

Crossref $\bullet$ PubMed $\bullet$ Google Scholar

11. Nasibian L.S., Filippov I.B. Modulation of rat myometrium contractile activity by peptidoglycan of Staphylococcus aureus cell wall. Fiziolohichnyı̆ zhurnal, 2014; 60(5): 62-72. (In Ukrainian) Crossref • PubMed • Google Scholar

ISSN 1996-4536 (print) • ISSN 2311-0783 (on-line) • Біологічні Студії / Studia Biologica • 2021 • Том 15 / № 2 • С. 3-14 
12. Pande J., Grover A.K. Plasma membrane calcium pumps in smooth muscle: from fictional molecules to novel inhibitors. Canadian Journal of Physiology and Pharmacology, 2005; 83: 743-754.

Crossref $\bullet$ PubMed $\bullet$ Google Scholar

13. Pehlivanoğlu B, Bayrak S, Doğan M. A close look at the contraction and relaxation of the myometrium; the role of calcium. Journal of the Turkish German Gynecological Association, 2013;14(4): 230-234.

Crossref • PubMed • PMC • Google Scholar

14. Reyes-García J., Flores-Soto E., Carbajal-García A., Sommer B., Montaño L.M. Maintenance of intracellular $\mathrm{Ca}^{2+}$ basal concentration in airway smooth muscle (Review). International Journal of Molecular Medicine, 2018; 42(6): 2998-3008.

Crossref $\bullet$ PubMed $\bullet$ PMC $\bullet$ Google Scholar

15. Shmigol A.V., Eisner D.A., Wray S. Simultaneous measurements of changes in sarcoplasmic reticulum and cytosolic. The Journal of Physiology, 2001; 531(Pt 3): 707-713.

Crossref $\bullet$ PubMed $\bullet$ PMC $\bullet$ Google Scholar

16. Strehler E.E. Plasma membrane calcium ATPases as novel candidates for therapeutic agent development. Journal of Pharmacy \& Pharmaceutical Sciences, 2013; 16(2): 190-206. Crossref • PubMed • PMC • Google Scholar

17. Testrow C.P., Holden A.V., Shmygol A., Zhang H. A computational model of excitation and contraction in uterine myocytes from the pregnant rat. Scientific Reports, 2018; 8(1): 9159. Crossref $\bullet$ PubMed $\bullet$ PMC $\bullet$ Google Scholar

18. Tsymbalyuk O.V., Kosterin S.O. Influence of calixarene C-90 on contractile activity of rat myometrium smooth muscles. Studia Biologica, 2013: 7(3); 5-20.

Crossref $\bullet$ Google Scholar

19. Tsymbalyuk O.V., Kosterin S.O. Thermomechanokinetics of viscoelastic deformation of smooth muscles in the rat gastrointestinal tract. I. Dynamic properties of the stretch in stomach smooth muskles. Studia Biologica, 2012: 6(2); 87-98.

Crossref • Google Scholar

20. Tsymbalyuk O.V., Kosterin S.O. Thermomechanokinetics of viscoelastic deformation of smooth muscles in the rat gastrointestinal tract. II. Thermomechanokinetics of hysteresis of stomach and largr intestine smooth muscles. Studia Biologica, 2012: 6(3); 73-84.

Crossref $\bullet$ Google Scholar

21. Tsymbalyuk O.V., Kosterin S.O. Thermomechanokinetics of viscoelastic deformation of smooth muscles in rat gastroitestinal tract. III. The work of the viscoelastic stretch of antral stomach smooth muscles. Studia Biologica, 2013: 7(1); 21-30.

Crossref • Google Scholar

22. Veklich T.O., Mazur lu.Iu., Kosterin S.O. $\mathrm{Mg}^{2+}$, ATP-dependent plasma membrane calcium pump of smooth muscle cells. II. Regulation of activity. The Ukrainian Biochemical Journal, 2015; 87(2): 5-25. (In Ukrainian)

Crossref $\bullet$ Google Scholar

23. Veklich T.O. The inhibitory influence of calix[4]Arene of C-90 on the activity of $\mathrm{Ca}^{2+}, \mathrm{Mg}^{2+}-$ ATPases in plasma membrane and sarcoplasmic reticulum in myometrium cells. The Ukrainian Biochemical Journal, 2016; 88(2): 5-15.

Crossref $\bullet$ PubMed $\bullet$ Google Scholar

24. Xu J., Menon S.N., Singh R., Garnier N.B., Sinha S., Pumir A. The role of cellular coupling in the spontaneous generation of electrical activity in uterine tissue. PLoS One, 2015; 10(3): e0118443.

Crossref • PubMed $\bullet$ PMC • Google Scholar

25. Wang Q., Wang K., Solorzano-Vargas R.S., Lin P.Y., Walthers C.M., Thomas A.L., Martín M.G., Dunn J.C.Y. Bioengineered intestinal muscularis complexes with long-term spontaneous and periodic contractions. PLoS One, 2018; 13(5): e0195315.

Crossref $\bullet$ PubMed $\bullet$ PMC $\bullet$ Google Scholar

26. https://www.who.int/news-room/fact-sheets/detail/preterm-birth

ISSN 1996-4536 (print) • ISSN 2311-0783 (on-line) • Біологічні Студії / Studia Biologica • 2021 • Том 15 / № 2 • С. 3-14 


\section{МОДУЛЯЦІЯ МЕХАНОКІНЕТИКИ СПОНТАННИХ СКОРОЧЕНЬ МІОМЕТРІЯ ЩУРІВ КАЛІКС[4]АРЕНОМ С-90 - ІНГІБІТОРОМ КАЛЬЦІЄВОЇ ПОМПИ ПЛАЗМАТИЧНОЇ МЕМБРАНИ}

\section{О. В. Цимбалюк}

${ }^{1}$ Київський національний університет імені Тараса Шевченка вул. Володимирська, 64/13, Київ 01601, Україна Кореспондуючий автор: e-mail: otsimbal@univ.kiev.ua

Обґрунтування. Кальцієва помпа плазматичної мембрани - конститутивна структура плазматичної мембрани клітин, яка виконує функцію високоафінної системи по виведенню іонів $\mathrm{Ca}^{2+} 3$ цитоплазми, забезпечуючи тривале підтримання базальної концентрації цих катіонів у стані спокою. Натепер немає задовільних засобів фрармакологічної корекції фрункції цього ензиму та залишається надзвичайно актуальним питання розробки, синтезу та дослідження на різних моделях сполук зі спрямованою дією на цю помпу. Попередньо нами встановлена здатність калікс[4]арену C-90 через NO-залежний механізм пригнічувати скорочувальну активність і уповільнювати розслаблення гладеньких м'язів міометрія, суттєво зменшуючи нормовану максимальну швидкість фрази релаксації.

Матеріали та методи. У роботи було досліджено механокінетичні закономірності впливу кумулятивного підвищення концентрації калікс[4]арену C-90 (10 нM 100 мкМ) на спонтанну скорочувальну активність міометрія щурів. Повний профріль спонтанних циклів скорочення-розслаблення досліджували за допомогою розробленого нами емпіричного багатопараметричного методу комплексного механокінетичного аналізу з розрахунком часових $\left(\tau_{0}, \tau_{\mathrm{C}} \mathrm{i} \tau_{\mathrm{R}}\right)$, силових $\left(F_{\max }, F_{\mathrm{C}}\right.$ та $\left.F_{\mathrm{R}}\right)$, швидкісних $\left(V_{\mathrm{C}}\right.$ i $\left.V_{\mathrm{R}}\right)$, а також імпульсних параметрів $\left(I_{\max }, I_{\mathrm{C}}\right.$ та $\left.I_{\mathrm{R}}\right)$.

Результати. Калікс[4]арен C-90 спричиняв дозозалежне пригнічення спонтанної скорочувальної активності препаратів міометрія. Його високі концентрації спричиняли зміну структури скоротливого акту, збільшуючи тривалість фрази скорочення та не впливаючи на тривалість фрази розслаблення. Також зі застосуванням багатопараметричного методу комплексного механокінетичного аналізу було встановлено, що сполука С-90 на всьому діапазоні досліджених концентрацій суттєво зменшує показники силових параметрів $\left(F_{\max }, F_{\mathrm{C}}\right.$ та $\left.F_{\mathrm{R}}\right)$, а також значення імпульсів сили $I_{\max }, I_{\mathrm{C}}$ та $I_{\mathrm{R}}$ спонтанних скорочень міометрія. На тлі дії усіх застосованих концентрацій $\left(10^{-7}-10^{-4} \mathrm{M}\right)$ калікс[4]арен C-90 спричиняв уповільнення релаксації спонтанних скорочень м'язових препаратів матки щурів, що відобразилось у достовірному зниженні максимальної швидкості фрази розслаблення $\left(V_{R}\right)$.

Висновки. Отримані результати вказують на те, що калікс[4]арен C-90 гальмує процеси екструзії $\mathrm{Ca}^{2+}$ з міоплазми, ймовірно, діючи безпосередньо на молекули кальцієвої помпи плазматичної мембрани. Варто відзначити, що С-90 також, імовірно, пригнічує процеси надходження цих катіонів до міоцитів, спричиняючи зниження швидкості наростання сили під час фрази скорочення, а також зменшуючи частоту і силу спонтанних скорочень міометрія.

Ключові слова: гладенькі м'язи, міометрій, кальцієва помпа плазматичної мембрани, калікс[4]арен C-90, механокінетичний аналіз

Received / Одержано 11 May, 2021
Revision / Доопрацьовано 26 May, 2021
Accepted / Прийнято 02 June, 2021
Published / Опубліковано 30 June, 2021

ISSN 1996-4536 (print) • ISSN 2311-0783 (on-line) • Біологічні Студії / Studia Biologica • 2021 • Том 15 / № 2 • С. 3-14 